\title{
Does It Really Matter? Assessing the Performance Effects of Changes in Leadership and Management Structures in Nordic Higher Education
}

\author{
Kirsi Pulkkinen, Timo Aarrevaara, \\ Laila Nordstrand Berg, Lars Geschwind, \\ Hanne Foss Hansen, Helge Hernes, Jussi Kivistö, \\ Jonas Krog Lind, Anu Lyytinen, Elias Pekkola, \\ Rómulo Pinheiro, Bjørn Stensaker, and Johan Söderlind
}

Helge Hernes passed away in the Fall of 2018.

\footnotetext{
K. Pulkkinen $(\bowtie) \bullet T$ T. Aarrevaara

Faculty of Social Sciences, University of Lapland, Rovaniemi, Finland e-mail: kirsi.pulkkinen@ulapland.fi; timo.aarrevaara@ulapland.fi

L. N. Berg

Department of Social Science, Western Norway University of Applied Sciences, Sogndal, Norway

e-mail: laila.nordstrand.berg@hvl.no

L. Geschwind • J. Söderlind

School of Industrial Engineering and Management, KTH Royal Institute of Technology, Stockholm, Sweden e-mail: larsges@kth.se; johanso2@kth.se

(C) The Author(s) 2019

R. Pinheiro et al. (eds.), Reforms, Organizational Change and Performance in Higher Education, https://doi.org/10.1007/978-3-030-11738-2_1
} 


\section{InTRODUCTION: RATIONALISATION AND CONVERGING Higher Education Policies}

As a sector of the economy, higher education has been the subject of substantial change in the last couple of decades, not least due to the exponential growth in the number of students and institutions, often seen as pertaining to the phenomena of massification (Trow and Burrage 2010). All over the world, organisational fields and their specific institutions, such as universities, have similarities in organisational design and activities. In many countries, universities have experienced a shift towards 'academic capitalism' (Slaughter and Leslie 1999) and are operating as 'entrepreneurial universities' (Clark 1998; Etzkowitz et al. 2008). Rationalisation of the universities as organisational actors has been done via the introduction of a more formal structure in terms of a stronger emphasis on quality assurance, evaluation, accountability measures and incentive systems. These can be considered a transnational process linked to the New Public Management (NPM) type of governance reforms (Ramirez and Christensen 2013; Seeber et al. 2015).

The social mechanisms of spreading ideas of rationalisation can be highlighted through the perspective of institutional isomorphism (DiMaggio and Powell 1983). Literature on isomorphism concentrates on the increasing similarity of organisational and institutional structures and

H. F. Hansen • J. K. Lind

Department of Political Science, University of Copenhagen,

Copenhagen, Denmark

e-mail: hfh@ifs.ku.dk; jkl@ifs.ku.dk

H. Hernes • R. Pinheiro

Department of Political Science \& Management, University of Agder, Kristiansand, Norway

e-mail: romulo.m.pinheiro@uia.no

J. Kivistö • A. Lyytinen • E. Pekkola

Faculty of Management and Business, Tampere University, Tampere, Finland e-mail: jussi.kivisto@tuni.fi; anu.lyytinen@tuni.fi; elias.pekkola@tuni.fi

B. Stensaker

Department of Education, University of Oslo, Oslo, Norway e-mail: bjorn.stensaker@iped.uio.no 
cultures. Studies on policy convergence instead focus on changes in national policy characteristics. Policy convergence, that is, the development of similar or identical policies across countries over time (Knill 2005), seems to be particularly evident in Nordic countries. They show similar types of policy development in many significant areas of higher education policy, particularly those related to governance.

One of the most important reasons behind policy convergence is international policy promotion, where an actor with expertise in a policy field promotes certain policies. International (or supranational) organisations specialising in certain policy fields are the main actors for inducing the convergence of policies. This happens when they actively promote certain policies and define objectives and standards, as well as arguments, to support their case in an international setting. Countries diverging from promoted policy models may feel pressure to comply with the policies (Holzinger and Knill 2005; Knill 2005).

There are two overarching international political processes relating to higher education in Europe which presumably have a significant impact on the policy convergence: the higher education 'Modernisation Agenda' (European Commission 2006, 2011), promoted under the auspices of the EU institutions (European Commission, in particular), and the intergovernmental Bologna process (Moisio 2014). Many of the NPM ideals implemented in Nordic universities, such as promoting the accountability and autonomy of higher education institutions and improving the governance, funding, quality and relevance of higher education, are directly aligned with the Commission's Modernisation Agenda. Interestingly, the Modernisation Agenda presents the American higher education system and universities in particular as one of the important points of comparison in developing European higher education (Slaughter and Cantwell 2012; Slaughter and Taylor 2016).

Similarly, the Bologna process seems to increase policy convergence at the European level, even though research evidence for this is not yet entirely clear (Witte 2008). However, Voegtle et al. (2011) found that higher education policies of Bologna participants converge more strongly and that the Bologna process has made a crucial difference in increasing the similarity of higher education policies. Particularly in the area of quality assurance, the majority of Bologna signatories implemented most of the measures. They also included all the required actors into their quality assurance measures according to Bologna standards by 2008 (Voegtle et al. 2011). 
Furthermore, international/intergovernmental organisations such as the Organisation for Economic Co-operation and Development (OECD), the World Bank and the United Nations Educational, Scientific and Cultural Organisation (UNESCO) are highly influential actors in higher education policy convergence (e.g. see Shahjahan and Madden 2015). At the European and Nordic level, the OECD has the most notably high level of impact on policy convergence. Nation states, including Nordic countries, often rely on the OECD to provide them with the latest data on trends, current issues and policy options. The OECD uses conferences, trend and review reports and the mediation of policy language to influence the thinking of national-level policymakers within and outside of its member countries (Shahjahan and Madden 2015). For instance, the OECD's thematic reviews can provide strong legitimisation or justification to national governments for initiating policy reforms, as has happened in Finland (Kallo 2009).

In addition to the influence of international organisations, crossnational policy convergence might simply be the result of similar but independent responses caused by the countries reacting to the same types of policy problems (Knill 2005; Bennett 1991). At the same time, convergence in policies is more likely in countries that are characterised by high institutional similarity. Policies tend to be implemented insofar as they fit with existing cultures, socio-economic structures and institutional arrangements. In their search for relevant policy models, states are expected to look to the experiences of those countries with which they share an especially close set of cultural similarities and ties (Knill 2005).

However, although policy convergence is clearly observable across the Nordic countries, it is important to note that similar policies are introduced at different points in time and with important variations in the details. For instance, all the Nordic countries have introduced performancebased funding systems linked to the distribution of resources for basic research. Yet, performance is measured using different indicators and redistribution potentials. The effects are also somewhat different. There seems to be more convergence in policy ideas and policy rhetoric than in actual policy implementation. Other examples of these dynamics are found in relation to the overall governance and management structures, as well as to the national quality assurance systems linked to education.

Reforms inspired by the NPM have had a profound effect on the internal structures and governance arrangements of public higher education institutions in the Nordic countries. The impact has been further 
strengthened by parallel calls for increasing accountability and efficiency (Pinheiro et al. 2014). Yet, few studies to date have systematically and comparatively investigated what types of effects the so-called modernisation efforts have had on teaching and research performance in publicly run and funded universities. This book responds to this gap in knowledge and brings forth new data and comparative analysis of universities in the Nordic countries.

The environmental conditions under which Nordic higher education institutions operate have changed dramatically in the last two decades. Policy efforts aimed at modernising the sector have paid considerable attention to the way in which public universities operate. A strong focus has been given to managerially inspired aspects, such as efficiency, effectiveness and accountability (de Boer and Enders 2017). In addition to managing their internal operations in more cost-efficient manners, public universities are increasingly expected to respond to the needs of various, rather different, external stakeholder groups. In light of the social contract that exists between the universities and society that, in essence, funds them, interacting with the surrounding society has become a task to be tackled actively (Fumasoli et al. 2014; de Jong et al. 2016). One of the many mechanisms being used to achieve these goals relies on enhancing the rationalisation of internal structures and activities by promoting professional management. As a result, most Nordic universities have developed extended administrative structures, ranging from central to unit levels. These structures have been designed to be capable of strategically supporting the primary activities of universities, that is, teaching and research (Amaral et al. 2003). Some have introduced changes in the nomination of formal leaders, that is, they are appointed rather than elected.

Reform efforts are both costly and demanding for the personnel. Therefore, it is necessary to monitor the extent to which they generate the expected results. Consideration should be given to the cost-efficient management of the universities as well as to the situations of the personnel whose task is to perform their duties according to the academic quality criteria in the midst of extensive reforms. As a key sector of the economy, it is necessary to take stock of the ways in which the higher education sector has changed performance-wise as a result of government-led and/or initiated reform efforts.

This is, in many ways, the case with Nordic countries, which are characterised by a welfare state ideology and development of the public sector within this framework. Moreover, they are relatively similar in 
terms of population size and geographical proximity and share the same type of political systems and political values. In terms of policy challenges, all Nordic countries have to deal with the financial, social and political sustainability of the Nordic welfare model which, in turn, as has been mentioned before, has triggered government-led reform efforts under the label of NPM, particularly in the higher education sector. In all countries, universities are expected to play an increasingly important role in local and national economic development and to spur innovation. Such expectations have further intensified government-led efforts to modernise the higher education sector in all Nordic countries but have also led to calls from the higher education sector to balance governmental funding and leeway regarding, for example, autonomy to better match with the growing demands for more diverse activities.

Before moving forward, we provide a brief note on the Nordic region, which is the geographical focus of this book. The Nordic region is situated in Northern Europe, and the Nordic countries are generally considered to include Denmark, Finland, Iceland, Norway and Sweden, including their associated territories (Greenland, the Faroe Islands and the Åland Islands) (Fig. 1.1). The region shares a strong cultural history and is known for its commitment to social-democratic values, equal opportunity and a generous but financially sustainable welfare state model (Hilson 2008). The Nordic region ranks rather high internationally across a multiplicity of comparative dimensions, ranging from innovation to trust in government to educational quality to quality of life. One of its great successes has been its ability to combine a strong safety net for its citizens, together with the adoption of market-based mechanisms (open economy) aimed at increasing its global competitiveness. When compared to other countries, and as a whole, the Nordics were able to withstand the pressures emanating from the 2008 financial crisis, despite being affected differently as a result of their economic profile and vulnerability to global export markets. That being said, as is the case elsewhere, the region faces a series of challenges, including but not limited to an ageing population, an over-reliance on particular industries (economic specialisation) and the need to reform the pension system (Norden 2014).

The next section provides information on the research project that provided the framework for the current volume. 


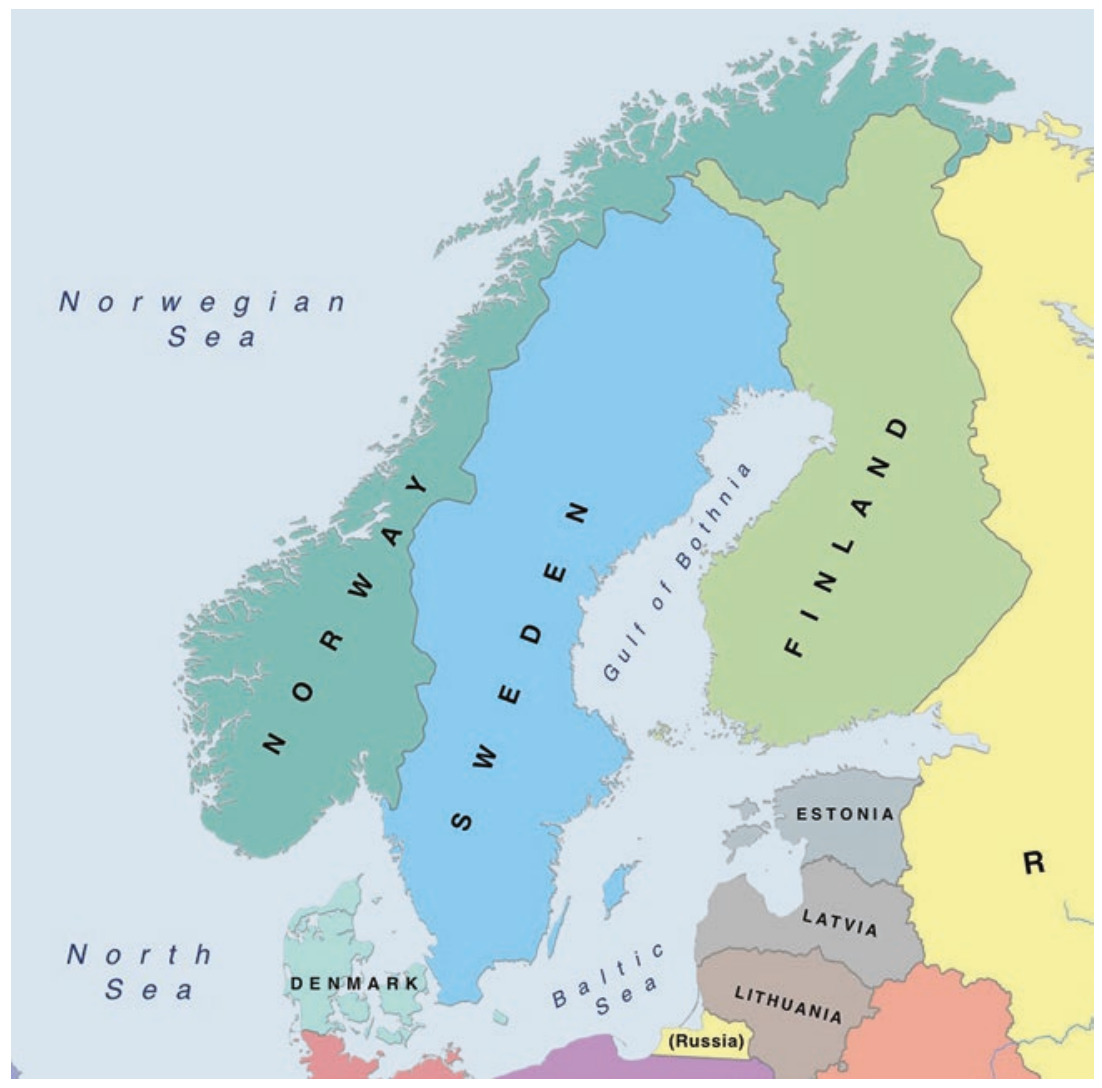

Fig. 1.1 The Nordic countries as the geographical focus of the book (excluding Iceland). Source: Mapswire.com. This work is licensed under a Creative Commons Attribution 4.0 International License

\section{THE FINNUT-PERFACAD STUdY}

\section{Aim and Research Problem}

This volume reports on the results emanating from a three-year (fall 2014-summer 2017) comparative, international research project entitled "Does It Really Matter? Assessing the Performance Effects of Changes in Leadership and Management Structures in Nordic Higher Education", funded by the Norwegian Research Council in the context of its FINNUT 
programme (Research and Innovation in the Educational Sector). The study's focus was on the relationship between changes in formal leadership structures and performance shifts and was substantiated around the following research problem:

- To what extent are changes in leadership and management structures related to shifts in teaching and research performance in public universities across the Nordic countries (Norway, Sweden, Denmark and Finland) in the last decade?

In doing so, it illuminated three key dimensions:

1. the key drivers promoting the rationalisation of academic activities in general and, specifically, the rise of managerialism within public universities,

2. the roles played by both internal (academics and administrators alike) and external actors in strengthening the managerial structures (central and unit levels) of universities and

3 . the effects of changes in leadership/managerial structures in the (teaching and research) performance of individual subunits, as well as in the behaviours of internal actors.

In a nutshell, the study provided both a quantitative assessment of formal structures and a qualitative interpretation of the meanings held by social agents (central and unit levels) associated with those same structures, for example, on being 'modern', 'responsive', 'accountable', 'entrepreneurial' and so on. Rather than simply focusing on generating new sets of empirical data, the study aimed to advance new perspectives for theorising ongoing rationalisation processes on the basis of the various disciplinary traditions and competencies brought together in the multidisciplinary research team, the core of which was composed of the authors of the current volume.

\section{Theoretical Foundation}

Organisations have traditionally been conceived as either instruments, or tools to reach certain ends (goals), or as institutions, that is, having lives of their own (Scott 2008). Both views have merits and provide important insights on the dynamics facing modern organisations across the public 
and private sectors. The rational view of organisations (c.f. Scott 2003: 33-55) views internal behaviour as resulting from the purposeful actions of a set of coordinated social agents within a given local setting (Battilana 2006; Hay and Wincott 1998). Key elements like goal specificity and the formalisation of structures and procedures are seen as critical to the 'rationality of organizational action' (Scott 2003: 34), therefore ranking high on the managerial agenda. The general assumption in the literature is that, as a process, rationalisation is, first and foremost, substantiated around the formal structure of organisations (Thompson 2008; Pfeffer 1997):

$[\ldots]$ in rules that assure participants will behave in ways calculated to achieve desired objectives, in cognitive decision-premises that guide individual decision making, in control arrangements that evaluate performance and detect deviance, in reward systems that motivate participants to carry out prescribed tasks, and in the set of criteria by which participants are selected, replaced, and promoted. (Scott 2003: 54; emphasis added)

The rational systems' view of organisations, vividly contested by many (March and Olsen 2006a), puts a preferential emphasis on the role of formalised rules (plans, strategies, programmes, etc.) and normative structures (roles, sanctions, regulations, etc.). In doing so, this view disregards more tacit dimensions, such as the effects of macro-level scripts (DiMaggio and Powell 1983) and the preferences and behavioural patterns of organisational participants (Powell and Colyvas 2008). Proponents of rational systems argue that structural (often hierarchical) arrangements play a critical role in the ways in which organisations interact with, and respond to, environmental demands (Selznick 1984). Leadership structures are celebrated, with the lower levels of the organisations primarily involved in the implementation, rather than problem assessment, of the key decisions undertaken at higher levels (Blau and Scott 2003).

In (continental) Europe, the basic structural features of academic organisations, that is, decentralisation of authority, loose-coupling of structures, multiplicity of tasks, unclear goals, complex technologies and so on (Pinheiro 2012; Clark 1983), have not traditionally been conducive to the implementation of centralised models of decision-making (Amaral et al. 2003). This is particularly the case when it comes to both the speed and scope of university responses to external demands (Hölttä and Karjalainen 1997). For example, Musselin (2007) contended that: 
[...] in universities, formal structures and procedures, even if numerous, rarely favor cooperation and coordination. They hardly define what to do and how to do it because of the specific characteristics of teaching and research $[\ldots]$ As a result, changing the formal structures most of the time has no effect $[\ldots]$ formal rules and structures weakly support hierarchical power. (Musselin 2007: 75)

Over the years and in many countries, including those within the Nordic region, the conception of traditional or classic research-intensive universities was that of 'ivory towers', that is, closed systems isolated from the dynamics of their surrounding environments (Etzkowitz et al. 2000). A key item in the policy agenda on national and supranational levels has been to institute a series of structural reforms in order to redesign universities. This is partly a result of the rise of a global knowledge-based society/economy (Maassen and Stensaker 2011) and partly due to the strategic imperatives surrounding the modernisation of the Nordic welfare state (Castells and Himanen 2004). This is particularly the case with those with a long historical record. The aim has been to make them more adaptive and responsive to external events and stakeholder demands (Maassen 2009; Etzkowitz 2001; Pinheiro and Stensaker 2013). In other words, ongoing reform processes aim at transforming public universities into organisational actors. There is a push towards becoming tightly integrated, goal-oriented and competitive entities which deliberately or strategically choose their own actions and are held accountable for their own behaviours (Krücken and Meier 2006; Ramirez 2010). In these circumstances, rationalisation measures such as the strengthening of managerial and leadership structures play an increasingly important role (Teichler 2005; Krücken 2011).

The view of universities as rational(ised) tools or instruments for reaching certain pre-determined goals or ends (Olsen 2007) pays considerable attention to the technical or material-resource features of the environment (c.f. Scott 2003: 133). These aspects are intrinsically related to the daily management and operations of universities, as well as their performance. In such circumstances, social agency is characterised by what March and Olsen (2006b) called the 'logic of consequences'. According to this logic, university actors behave in ways that are congruent with the successful realisation of strategic objectives either set internally by the central administration or emanating from the outside (government/funding agencies). For example, this is clearly visible in the prominence given to contractual 
arrangements (Gornitzka et al. 2004) and/or the rise of what Rip (2004) has termed 'strategic science regimes' in academia.

Yet, there are those who have convincingly argued that most organisations, universities included, are not simply instruments or tools at the mercy of certain internal (managers) or external (governments) social agents (Selznick 1966; Olsen 2007). They contended that internal rules, both formal and informal, and standard operating procedures like the allocation of academic power or authority (Tapper and Palfreyman 2011) cannot be changed arbitrarily (Maassen 2009; Maassen and Olsen 2007). Prior consent from academics at the unit level is similarly necessary for the definition of university strategic objectives (Zechlin 2010). Such limitations are seen to safeguard what Clark (1998) referred to as the academic heartland. This is the view held by most institutional scholars who, amongst other aspects, have argued against the limitations of 'means-ends rationality' while assessing change dynamics within organisations (Greenwood et al. 2008; Powell and DiMaggio 1991), universities included (Maassen and Olsen 2007; Pinheiro et al. 2012; Gornitzka 1999).

Regarding the rationalisation processes, it is worth bearing in mind that this is far from unique for the higher education sector. It follows the rationalisation of administrative structures across the entire public sector and even across the entire organisational landscape (Brunsson and SahlinAndersson 2000). Thus, studies shedding light on ongoing attempts at transforming public organisations along the lines of New Public Management reform regimes (Christensen and Lxgreid 2007; Hood 1991, 1995) provided important insights for our study. We paid particular attention to the nature and degree of response to such transformative processes by social agents at the local (micro) level (Oliver 1991; Powell and Colyvas 2008) within the broad context of mimetic isomorphic processes/collective rationality (DiMaggio and Powell 1983) and the need for securing (internal and external) legitimacy (Deephouse and Suchman 2008). This includes, but is not limited to, the role played by such critical aspects as the de-coupling of structural arrangements (Bastedo 2007) and/ or their contextualisation or local translation (Czarniawska-Joerges and Sevón 2005). 


\section{Conceptual Backdrop}

\section{Visions of the University}

The study's conceptual framework is built on the work of Johan P. Olsen (2007) on the visions of the (European) university. Olsen made a distinction between an instrumental and institutional view of universities. In the former, the focus is on universities as means to achieve certain predetermined ends (e.g. policy goals or managerial aspirations); the latter sheds light on the university as a relatively independent fiduciary institution characterised by a life (norms, identity, inner dynamics) of its own. Following seminal work on formal organisations (Cohen and March 1974; March and Olsen 1979; Olsen 1988), Olsen advanced four stylised visions, or a typology (along two dimensions; autonomy vs. conflict), on the modern university. The typology was based on different assumptions about what the university is for as well as the circumstances under which it will operate appropriately. At the heart of Olsen's inquiry was this question: what type of university for what type of society? (Table 1.1).

The four visions represent key features of universities as organisations and institutions. They are thought to be complementary rather than mutually exclusive, that is, key features associated with the four visions are present at any moment in time, shaping dynamics within a given organisation:

The four stylized visions are based on assumptions which make it unlikely that any of them alone can capture current university practices. As less than perfect approximations to the abstract visions, universities as practices show "a shocking diversity" (Neave 2003: 151), and the relations between universities, public authorities and society are characterized by a great variety of forms of interaction, intervention and control (Hood et al. 2004: Part III). (Olsen 2007: 33)

In the FINNUT-PERFACAD study, an issue of particular relevance was that of the interplay between different types of actors and their various roles in the broader higher education system. First, the interplay between internal and external dimensions of universities places pressure on the university governance systems. This reflects the instrumental view in Olsen's typology, as the interplay presumes that expectations exist between the external stakeholders and the internal university dynamics. It further implies that these expectations are mutual, that is, directed not only from 
Table 1.1 Visions of the European university

\begin{tabular}{|c|c|c|}
\hline$A u t$ & $\begin{array}{l}\text { University operations and } \\
\text { dynamics are governed by } \\
\text { internal factors }\end{array}$ & $\begin{array}{l}\text { University operations and dynamics } \\
\text { are governed by environmental } \\
\text { factors }\end{array}$ \\
\hline $\begin{array}{l}\text { Actors have } \\
\text { shared } \\
\text { norms and } \\
\text { objectives }\end{array}$ & $\begin{array}{l}\begin{array}{l}\text { The University is a self-governing } \\
\text { community of scholars }\end{array} \\
\text { Constitutive logic: } \\
\text { Free inquiry, truth finding, rationality } \\
\text { and expertise. } \\
\text { Criteria of assessment: } \\
\text { Scientific quality. } \\
\text { Reasons for autonomy: } \\
\text { Constitutive principle of the University } \\
\text { as an institution: authority to the best } \\
\text { qualified. } \\
\text { Change: } \\
\text { Driven by the internal dynamics of } \\
\text { science. Slow reinterpretation of } \\
\text { institutional identity. Rapid and radical } \\
\text { change only with performance crises. }\end{array}$ & 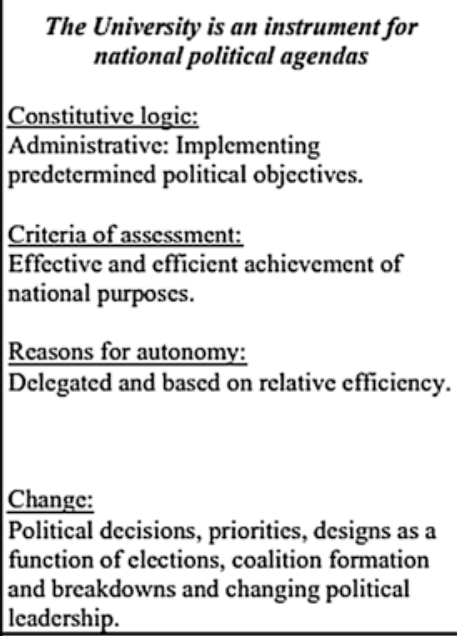 \\
\hline $\begin{array}{l}\text { Actors have } \\
\text { conflicting } \\
\text { norms and } \\
\text { objectives }\end{array}$ & $\begin{array}{l}\text { The University is a representative } \\
\quad \text { democracy }\end{array}$ & $\begin{array}{l}\begin{array}{l}\text { The University is a service enterprise } \\
\text { embedded in competitive markets }\end{array} \\
\text { Constitutive logic: } \\
\text { Community servicc. Part of a system of } \\
\text { market exchange and price systems. } \\
\text { Criteria of assessment: } \\
\text { Mecting community demands. Economy, } \\
\text { efficiency, flexibility, survival. } \\
\text { Reasons for autonomy: } \\
\begin{array}{l}\text { Responsiveness to "stakeholders" and } \\
\text { external exigencies, survival. }\end{array} \\
\text { Change: } \\
\begin{array}{l}\text { Competitive selection or rational learning. } \\
\text { Entreprencurship and adapting to changing } \\
\text { circumstances and sovercign customers. }\end{array}\end{array}$ \\
\hline
\end{tabular}

Source: Olsen (2007: 30). Figure used with permission from Springer. 
the external inwards but also from the university towards the external players. The second interplay refers to the degree of internal conflict within the university institutions, which relates to the institutional view in Olsen's typology. It presumes that there is a shared foundation in the core values of the university institution. However, it accounts less for the differences in which the multiple professions in universities adapt to changes in the operational and working environment. In short, the university institution is seen to function in a constantly changing context in which a multiplicity of adaptive measures are necessary. Next, we inspect the different dimensions of interplay which formed a core qualifying factor for Olsen's typology and furthered the conceptual framework for our study.

\section{Adaptation of University Governance Between Multiple Pressures}

Higher education institutions are public organisations and operate in a highly institutionalised environment (laden with rules, regulations and procedures). They are heavily dependent on public resources to finance their core activities. As such, higher education institutions are susceptible to shifts in governance arrangements. Yet, these internal changes do not occur in a linear manner, and universities are far from being passive recipients of reform agendas. As institutions, universities have both a history and lives of their own. They are also characterised by multiple internal constituencies (academics, administrators, students, managers). Universities have traditionally been bottom heavy and loosely coupled organisations which change only through minor local adjustments and where academics have had a lot of autonomy to act and direct their own activities (Bleiklie et al. 2017; Clark 1983; Fumasoli and Stensaker 2013; Weick 1976). Internal factors have traditionally been essential in the governance of university dynamics, and a kind of vision of the university has been 'a self-governing community of scholars' (Olsen 2007).

Historically speaking, universities have proven to be rather resilient to shifts in political orientations and economic regimes. They are able to decouple themselves from short-term political imperatives (Bastedo 2007). However, due to globalisation, knowledge society development, changes in political thinking and financial stringency, universities are increasingly embedded in competitive markets, wider material resources and institutional environments. They have social connections, not only to internal academic constituencies and disciplines but also to policymakers and other external stakeholders (Bleiklie et al. 2017; Scott 2003; Williams and Kitaev 2005). This implies that universities are increasingly governed 
with external environmental demands and factors (Olsen 2007). All these aspects (and others) play an important role in the ways in which universities respond to shifts in government policy.

In looking at the reforms of public institutions' autonomy in general and university organisations in particular, assumptions regarding the rationale for autonomy appear. One key assumption is that reforms can be implemented only if administrative autonomy is strengthened. Such actions come tied to increased external result control, financial incentives and competitions (Fumasoli et al. 2014). This constitutes a double-edged sword: while input autonomy is granted to the public organisation, output control is kept tightly in the hands of the government (Verhoest et al. 2004). A second key assumption is the expectation that autonomy will semi-automatically strengthen competitiveness and specialisation, thus being beneficial to the public institution in comparison to other similar organisations acting in the same market (Fumasoli et al. 2014). Effectiveness, economic efficiency and a better competitive edge with regard to quality through prioritisation are expected to follow as a result of increased autonomy.

The interaction between the state and universities can be viewed as an interdependent principle-agent relationship (de Jong et al. 2016). Rational choice theory guides the thinking in which the institutional leadership of the agent is seen to lean on self-interest, while the principal requires control mechanisms as well as incentives to guide the action (Fumasoli et al. 2014). A social contract exists between the two actors in which the state provides funds to universities to perform research and teaching of the highest level. Policymakers need the information produced by the universities, not only for society at large but also, and in particular, to provide guidance on how to tackle complex and often ambiguous policy problems. Knowledge regimes, such as universities, act as sense-making apparatuses. In policy settings, sense-making includes power struggles as well as contestations and negotiation. Similarly, in universities, sensemaking processes vary depending on how they are organised (Campbell and Pedersen 2014).

The policy guidance and control provided by the state (funder) to the universities in return for services rendered constitute a form of a social contract. Relevance of science to society is a central aspect of the contract. However, the meaning of relevance is not a constant; rather, it evolves in time and reflects the general societal development. Relevance changes over time in line with the ideas of what benefits science can bring to society 
(Hessels et al. 2009). Knowledge regimes are fields of the policy research organisations and institutions that govern them. They are organisational and institutional machineries that generate data, research and policy recommendations, as well as other ideas that influence policy debate (Campbell and Pedersen 2014). The idea follows the same line of thought as Olsen's typology (2007), where the universities may be seen as instruments of national policies while also as leaning on a base of a community of scholars. In other words, universities are expertise-based institutions that simultaneously aim to influence policies proactively and respond to policy initiatives reactively.

The relationship between the state and the universities can be seen as based on highly different grounds. Universities have traditionally viewed themselves as communities of scholars where strong autonomy guarantees high quality and trustworthy research and teaching (Olsen 2007). As a result of this view, society is considered to benefit from a strong science basis without unnecessary middlemen. The state can be seen to sell the university free hands to manage its tasks in the way it sees fittest. In contrast - and juxtaposing this view with another classification of Olsen's typology-the university is an instrument of national policies. The state funds research and highest teaching with the condition that the university performs its duties in a transparent and cost-efficient manner (Olsen 2007). As a result, tax funds are used to support the development of society in ways that are deemed relevant. Activities are reported responsibly and in a way that demonstrates the accountability of the university institution towards the state funder and broader society. However, the autonomy of science is dependent on a non-autonomous economic and management system.

The concept of universities as specific kinds of organisations with limited rationality and loosely coupled has begun to change. The institutional form of universities lives in the midst of a socio-political (and economic) struggle characterised by pressures to reconsider their role, regulatory practices and funding arrangements, as well as the processes that link universities to other societal actors. Now, universities are increasingly transforming into penetrated hierarchies that are managed organisations with a central leadership and formalised rule systems (Bleiklie et al. 2015). Strategic actorhood has become a key aspect in this. Penetrated hierarchies balance between multiple pressures from a broad range of external actors and stakeholders who hold power in the funding and prestige of the universities. As such, this creates a dependence that affects the internal power 
structures, control mechanisms and working practices of universities. The academically focused pressures have been joined by managerial performance demands, not only from the government but also from other external actors who share an interest in how the university institution is managed. Yet, the ability of universities to respond to the external pressures to, for example, innovate and develop organisational strategies is dependent on the availability of resources from a number of actors (Whitley 2008).

The development of universities as particular types of strategic actors relies heavily on the policies of governments, in particular, regarding their role in steering. National politics and the governance of universities are strongly coupled through the implementation of policies, despite the formal autonomy of universities. The linkage has often been approached from a point of view of dichotomy, where the autonomy of universities and the external steering of them are seen as opposing poles (Stensaker 2014). In an attempt to move beyond a top-down/bottom-up dichotomy and a duel-based view of the governance model, Sabatier (2005) applied a more general policy implementation toolset for the analysis of universitystate relationships. In this model, the study of policy implementation is approached with institutional learning as a central element. Though the top-down perspective allows the study of learning amongst proponents of a particular reform, it is ill-suited to similar studies amongst opponents of the reform. According to Sabatier, this lack can be rectified by looking at the strategies with which the bottom-uppers (the opponents) aim to strengthen the attainment of their goals. Sabatier called for the combination of the top-down and bottom-up approaches in the analysis to avoid a bias towards the proponents or opponents. In order to allow for the learning and systematic change (rather than ad hoc deviance from the norm), a period of at least a decade is necessary (Sabatier 2005).

Finally, the interplay between the university governance and political landscape can also be investigated based on the operational logics that are used. Universities work with a dynamic operational logic in their external relations and with an organic logic in the internal environments (Ståhle and Åberg 2012). The former outlines the conditions for the relationship between university actors and external stakeholders, while the latter defines the rationale for cooperation with actors outside academia. In a dynamic working environment, university actors network with other independent actors. The actors have a self-determined relationship with each other, and they can be seen to gain mutually from the interaction. Universities are 
not considered to simply react to changes in their surrounding environment and/or act as instruments for national political agendas (Olsen 2007), but are presumed to influence their working context themselves. Universities can, then, be seen as active elements of policy planning processes, provided they have the will and skills to act.

The way universities interact with the policy planning actors is, however, also linked to the internal working environment. In the modern context, universities function as a type of representative democracy (Olsen 2007) in the midst of managerial pressures. This democracy continues to rest on the ideals of academic freedom, broad interest representation, an open discussion culture and respect for the self-correcting mechanism of science - in essence, the academic heartland (Clark 1998). In the Nordic context, the democratic aspect includes an active organisation of student representation and involvement in the formal structures of the university. The systems have been built to be responsive to the needs of the groups whose work and study conditions are affected by collective decisions regarding the running and structure of the university. In such an organic working environment, dialogue and exchange of experiences and feedback are central building blocks in developing functions and academia (Ståhle and Åberg 2012). It can be argued that the core skills for dialogue exist in the conventional academic environment. Thus, the issue becomes whether these skills can be transferred and adapted for use in interaction with the university management and policy planning actors.

The interplay between shifts in governmental policy, university governance and internal university dynamics form a complex, continuously changing system. In the Nordic context the converging policies form a dimension that affects the way the national systems develop. These constitute a moulding tool that can either support system development or act as a hindrance to organisational learning.

\section{Operationalisation of the Conceptual Framework}

In order to operationalise the study, six organisational/management mechanisms related to organisational performance were identified (see later). A shared understanding of what performance means in an academic university context was formed in order to ensure a coherent approach to the major issue at hand. An in-depth discussion on the meaning of performance, as well as other central concepts such as accountability, are included 
in Chap. 2 of this volume. Extant literature on organisations more generally, as well as on the nature of higher education systems and universities more specifically, was used to sketch these. These mechanisms are as follows:

- Strategy

- Decision-making structures

- Organisational structures

- Accountability measures

- Funding arrangements

- Cultural climate

The study acknowledged that modern universities are complex organisations, and that performance can be achieved in multiple ways. As such, 'NPM/modern reforms' is a messy concept; therefore, it was necessary to decompose what so-called new management structures imply for university performance. The six identified mechanisms were a way to acquire more knowledge about what the relationship is between management/governance structures and performance. The next step was to formulate the basic assumptions underpinning the study in light of the research problem following Olsen's work, ${ }^{1}$ namely:

- there is a direct positive link between governance/management structures and performance (instrumental argument),

- there is a direct negative link between governance/management structures and performance (institutional argument) and

- there are a number of contingencies between governance/management structures and performance (matching instrumental and institutional views).

A series of core hypotheses for each of the six mechanisms were then identified, driving the development of the survey questionnaire and

\footnotetext{
${ }^{1}$ Analytically, Olsen's four stylised visions models can be reduced to two broad ideal types or archetypes, instrument and institutional or cultural views, with models being 'variants' of these archetypes. 'Market' models also assume a kind of rationality that build on the same mechanisms as the instrumental model. The 'democracy' model builds on a normative assumption about the legitimacy of participation, which connects back to the institutional or 'cultural' model.
} 
interview guide. ${ }^{2}$ These mechanisms are described in some detail later. It should be noted that while these hypotheses were not tested per se in the study, they were instrumental in developing the conceptual framework into a coherent structure. They played an important role as we designed the operationalisation for the gathering of quantitative and qualitative data. The hypotheses were used, for example, to ensure that the two sets of data corresponded with each other and could be utilised to study the same phenomena in a comparable and complementary manner. We return to these hypotheses in the concluding chapter of this book to reflect on their role and meaning in the empirical analysis of our data. The methodological considerations are discussed in more detail in the latter part of this chapter.

\section{Strategy}

- H0: an overarching and penetrating institutional strategy boosts performance

- Hl: an overarching and penetrating institutional strategy alienates staff and negatively affects performance

- H2: strategies that are developed through participation boost performance

\section{Decision-Making Structures}

- H0: more hierarchical decision-making structures stimulate increased performance

- Hl: more hierarchical decision-making structures negatively affect performance

- H2: participatory decision-making structures stimulate increased performance

\footnotetext{
${ }^{2}$ In order to operationalise the study empirically, a series of key questions were devised around eight key themes associated with each of the six mechanisms described above (consult Table 1.5 and interview guide and survey template in Appendix). The empirical evidence provided in Part II of this volume sheds light on key findings along selected core themes, emanating from the survey questionnaire and the interview data.
} 


\section{Organisational Structure}

- H0: larger, more interdisciplinary structures boost performance

- Hl: larger, more interdisciplinary structures negatively affect performance

- H2: diverse structures are best fitted to the diversity found in universities, and diversity boost performance

\section{Accountability Measures}

- H0: more systematic and regular (intense) reporting boost performance

- $\mathrm{Hl}$ : more systematic and regular (intense) reporting negatively affects performance

- $\mathrm{H} 2$ : it is the way and form of reporting that affect performance

\section{Funding Arrangements}

- H0: more incentive and result-oriented funding boosts performance

- Hl: more incentive and result-oriented funding negatively affects performance

- H2: a mixed funding arrangement is the best way to boost performance

\section{Cultural Climate}

- H0: systematic training and competence building in the organisation boost performance

- Hl: systematic training and competence building (takes time away from primary activities and) negatively affect performance

- H2: cultural change through participatory and trust-based processes drives performance

In addition to shedding light on the relationship between the identified mechanisms associated with new management structures and performance, the study also aimed at exploring: 
- the linkages amongst the (six) mechanisms, for example, strategy is only effective if combined with hierarchical management and accountability measures;

- the possible tensions between the (six) mechanisms, for example, the existence of a strategy arguing for a particular profiling of the organisation may collide with pressure to achieve results in a shorter time frame; and

- the relative importance of institutional governance/management structures in relation to national steering frameworks, for example, whether national models override what single universities try to do and how they are organised.

Finally, the study aimed to provide new theoretical explanations for how changes in university governance can be interpreted in light of the extant literature and major organisational and public administration theories. Our interest was in the linkages between formal change and performance, although not in a strict causal sense.

\section{Research Design and Methodological CONSIDERATIONS}

This FINNUT project adopted a comparative research design and applied a mixed methods approach (Bryman 2006) comprising a desk-top analysis, surveys and interviews (see Appendix). While the time period 2000-2013 was set as the focus of study, some of the thematic analysis included developments until 2016 in order to respond to recent changes brought up in the empirical data, in particular, in the interviews. The desktop analysis consisted of major policy initiatives with national statistics and other official documentation on performance data related to education, research and management of the higher education sector. Such registerbased and performance-related data can be compared across countries and institutions (Ragin and Rihoux 2009). The data provided background material for the further development of the study (in the form of a comprehensive database), and relevant information has been utilised in the individual chapters composing this volume. A large set of new empirical data was collected through surveys and interviews.

The target groups of the survey were full-time managerial staff and academics employed at the 54 publicly run universities in Denmark, 
Finland, Norway and Sweden. The survey took place at the end of 2014 and the beginning of 2015. The sampling and the definition of the population was done differently in the four countries because of different national higher education systems, availability of sampling frames and also considering the different information needs of national research teams. Table 1.2 describes the study's population, sampling and response rate.

The national samples were planned in a manner that allowed for Nordic comparisons. The comparative international subsamples included the respondents working in senior positions (European career levels III and IV) in official management positions or in ordinary academic positions.

Table 1.2 Survey population, sampling and response rate

\begin{tabular}{|c|c|c|c|c|}
\hline & Population & Sampling & $\begin{array}{l}\text { Response } \\
\text { rate }\end{array}$ & $\mathrm{N}$ \\
\hline \multirow[t]{2}{*}{ Denmark } & Institutions: All & Managers & $\mathrm{N} / \mathrm{A}$ & 334 \\
\hline & $\begin{array}{l}\text { Staff categories: II, III, IV } \\
\text { (assistant, associate and } \\
\text { professor levels, including } \\
\text { post docs and managers) }\end{array}$ & $\begin{array}{l}\text { Academics } \\
\text { (census study) }\end{array}$ & $17 \%$ & 1989 \\
\hline \multirow[t]{4}{*}{ Finland } & $\begin{array}{l}\text { Institutions: All } \\
\text { Staff categories: III, IV }\end{array}$ & $\begin{array}{l}\text { Managers: - } \\
\text { (census) }\end{array}$ & $44 \%$ & 199 \\
\hline & $\begin{array}{l}\text { Managers: (deans, vice- } \\
\text { deans, heads of departments, } \\
\text { vice-heads of departments) }\end{array}$ & $\begin{array}{l}\text { Academics: Systematic } \\
\text { random sample (every } \\
\text { second) }\end{array}$ & $24 \%$ & 757 \\
\hline & Academics: (University & & & Total: \\
\hline & $\begin{array}{l}\text { lecturers/researchers, } \\
\text { associate professors, research } \\
\text { directors, professors) }\end{array}$ & & & $1038^{\mathrm{a}}$ \\
\hline \multirow[t]{2}{*}{ Norway } & Institutions: All & - & $10 \%$ & 1300 \\
\hline & Staff categories: All & (census study) & & \\
\hline \multirow[t]{2}{*}{ Sweden } & $\begin{array}{l}\text { Institutions: } 10 \text { out of } 16 \\
\text { public universities }\end{array}$ & $\begin{array}{l}\text { Managers: - } \\
\text { (census) }\end{array}$ & $16 \%$ & 700 \\
\hline & $\begin{array}{l}\text { Staff categories: II, III, IV } \\
\text { (all academics, including } \\
\text { managers, excluding PhD } \\
\text { candidates) }\end{array}$ & $\begin{array}{l}\text { Academics: Stratified } \\
\text { (Systematic random } \\
\text { sampling }(1 / 4) . \text { Small } \\
\text { institutions }(<800 \\
\text { academics) simple random } \\
\text { sampling of } 200)\end{array}$ & & \\
\hline
\end{tabular}

${ }^{\mathrm{a}}$ Of the respondents, 73 did not report about their title, and 9 individuals worked primarily outside Finland 
Table 1.3 Comparative samples of managers and senior academics ${ }^{a}$

\begin{tabular}{lcc}
\hline & $\begin{array}{c}\text { Seniors in official } \\
\text { management positions }\end{array}$ & $\begin{array}{l}\text { Seniors not holding official } \\
\text { management positions }\end{array}$ \\
\hline Denmark & 319 & 1319 \\
Finland & 258 & 660 \\
Norway & 143 & 721 \\
Sweden & 215 & 289 \\
Total & 935 & 2989 \\
\hline
\end{tabular}

aQuestion: 'Do you hold an official management position?'

The comparative samples are described in Table 1.3. Because the management positions differ from country to country, in comparative samples, the variable 'are you holding an official management position?' was used as a categorising variable. This means that the distinctions between academics and academic managers are based on the respondents' own reporting. The Nordic comparisons were made by using subsamples that best fit for the purpose. For instance, in some cases, it was better to compare only heads of departments and deans, whereas, in other cases, it was more suitable to work with the self-reported official management positions.

The most inevitable limitations of the data pertain to the fact that it describes subjective performance, that is, the performance as experienced and reported by the informants. During the research project, a large amount of statistical data on actual (objective) performance was also collected from each country. However, due to the long timescale of the academic performance, national differences in performance measurement and intervening variables, the connection between survey data and statistical data was statistically difficult to establish. Therefore, the survey findings described and explained the subjective performance (Kivistö et al. 2017).

For the interviews, we selected two case universities in each of the four countries. We chose to perform the interviews at one of the flagship universities in each country and one regional university. The case universities were multidisciplinary, and the inclusion criteria were that the universities have both natural (including medicine) and social sciences. Within the institutions, we selected participants strategically based on their official positions in the system. These positions were senior academics from the social and the natural sciences, managers from different levels who mainly 
had academic backgrounds and professionals in central administration dealing particularly with issues relating to research and teaching, as well as their development. Overall, a total of 93 interviews were conducted between the springs of 2015 and 2016 (Table 1.4).

A common interview guide was developed. As the selected participants were highly educated people and experts in their fields, we used the elite interviewing approach (Aberbach and Rockman 2002; Goldstein 2002). Such an approach puts an emphasis on giving room to the interviewees to talk freely on the presented themes while ensuring that the different themes are covered so as to be able to compare findings across the cases. A semi-structured interview approach was selected, and the questions were adjusted to the knowledge of the participants.

Since quantitative methods are more suitable for providing an overview from a larger audience, and the ability to dig deeper into a theme follows qualitative methodologies, different questions were posed in the survey and interviews. The questions evolved around similar themes (see Table 1.5) per the conceptual and analytical framework adopted in the study, as sketched out earlier. The qualitative data generated by the interviews aimed at shedding light on the main drivers of and reactions to

Table 1.4 Number of interviewees per country

\begin{tabular}{lccccc}
\hline & Denmark & Finland & Norway & Sweden & Total \\
\hline Managers and administrators & 17 & 14 & 18 & 9 & 58 \\
Academics & 11 & 10 & 8 & 6 & 35 \\
Total & 28 & 24 & 26 & 15 & 93 \\
\hline
\end{tabular}

Table 1.5 Themes for primary data collection

\begin{tabular}{ll}
\hline Survey themes & Interview themes \\
\hline Perceived performance & Goal specificity and degree of autonomy \\
Goal specificity and autonomy & Decision-making and strategy \\
Decision-making and strategy & Control and evaluation \\
Control and evaluation & Support structures \\
Support structures & External stakeholders \\
External stakeholders & Trust and accountability \\
Trust and accountability & Incentives/recognition \\
Incentives &
\end{tabular}


rationalisation processes. The data also helped identify qualitative effects across teaching and research activities. This way of collecting data increased the study's external validity (Denzin and Lincoln 2011). SPSS was used in the analysis of the statistical data. A systematic content analysis of the qualitative data was conducted using Nvivo.

Ethical guidelines were followed in the collection, publishing and the storing of data. We assured the anonymity of the participants in the datacollecting phase, and we referred to them in an anonymised manner related to the flagship/regional universities, positions and fields (consult Part II of the volume). The project was reported to and approved by the Norwegian Centre for Research Data, which also stored the anonymised quantitative data.

There were certain limitations which had to be accounted for through the analysis phase of the project. Due to different access requirements in administering surveys in the case countries, four individual approaches were applied. Some country teams sent the survey to all the academic staff, while others sent it to selected groups, as described earlier. This bias had to be addressed while selecting groups for the analysis of statistical data so that the same type of data were included in the comparisons. Another issue was the different organising structures of higher education institutions within the Nordic countries. This also had to be scrutinised, as we were comparing findings across cases and countries. A strategy to deal with these critical issues and to increase the reliability of the data was to include researchers with knowledge of the specific countries in each of the project's publications. ${ }^{3}$ The semi-structured interview approach also made it more difficult to analyse the material when compared to fully structured interviews. This approach requires a more thorough reading and inductive approach to the data. The teams used a similar concept tree structure in the content analysis of the interview data to increase comparability between the countries.

\footnotetext{
${ }^{3}$ In the case of the current volume, each chapter (with the exception of Chap. 6) has at least one co-author from each of the four countries, and all the individual chapters have been peer reviewed by an editorial board composed of senior authors from the region who were also directly involved with the study, as either team leaders and/or members.
} 


\section{The Volume's Organisation and Individual Contributions}

As indicated in section "Introduction: Rationalisation and Converging Higher Education Policies" of this chapter, the volume reports on the results of a comparative project that assesses the interplay between changes in leadership and management structures in public universities across the Nordic countries and shifts in teaching and research performance in the last decade and a half. The chapters included in this book illuminate the key aspects associated with some of the thematic areas presented earlier from a comparative perspective. However, each chapter stands on its own, both conceptually and empirically, and can be read separately. The overall results should, however, be assessed against the backdrop of the larger project that was undertaken.

This book is structured into three distinct Parts. In Part I, the first chapter sets the context and presents the rationale for and the design of the FINNUTPERFACAD study and elaborates on the theoretical foundations and conceptual landscape underpinning it. Chapter 2 by Kivistö et al. provides clarification on the key terminology underpinning the study, including contextualisation within a Nordic setting. The book then moves on to Chap. 3 where Pinheiro et al. describe the system evolution, as well as the higher education systems of each of the four Nordic countries. Part II of the book is dedicated to thematically focused chapters. While all of them lean on the same conceptual backbone that encompasses the study as a whole, each of the chapters adopts its own theoretical approach to the question at hand. The chapters begin from the system level and move towards the institutional.

Part II begins with Chap. 4 by Söderlind, Berg, Lind and Pulkkinen on how research funding systems at the national level affect local perceptions of research as a core task. Chapter 5, by Lind, Hernes, Pulkkinen and Söderlind, elaborates on the role that increasing levels of external funding play on the experiences of autonomy and how the effects on academic freedom are felt in research work. In Chap. 6, Geschwind, Berg, Lind and Aarrevaara investigate the evolving roles of academic leaders and managers amidst reforms that emphasise performativity alongside academic virtues. Chapter 7, by Aarrevaara, Pinheiro and Söderlind, explore the various ways in which strategic processes play out within Finnish, Norwegian and Swedish universities. Chapter 8, by Hansen, Aarrevaara, Geschwind and Stensaker, undertakes a comprehensive approach to evaluation practices by bringing together some of the topics discussed in the other chapters composing Part II of the volume. 
In Part III, we return to look at the results of the FINNUT-PERFACAD study as a whole. Led by Geschwind, the volume editors take a step back to reflect on where we started and what we have learnt on the journey this comparative study has taken us on. In closing the volume, the editors contemplate on next steps and potential new avenues for future research endeavours.

Acknowledgements The data presented in the current volume and individual chapters emanate from a comparative study funded by the Norwegian Research Council under its FINNUT flagship program, a long-term program for research and innovation in the educational sector program. The project number was 237782, and the project was titled 'Does it matter? Assessing the performance effects of changes in leadership and management structures in Nordic Higher Education'.

\section{REFERENCES}

Aberbach, Joel D., and Bert A. Rockman. 2002. Conducting and Coding Elite Interviews. Political Science \& Politics 35 (4): 673-676.

Amaral, A., V.L. Meek, and I.M. Larsen. 2003. The Higher Education Managerial Revolution? Dordrecht: Kluwer Academic Publishers.

Bastedo, M.N. 2007. Sociological Frameworks for Higher Education Policy Research. In Sociology of Higher Education: Contributions and Their Contexts, ed. P.J. Gumport, 295-318. Baltimore: The Johns Hopkins University Press.

Battilana, J. 2006. Agency and Institutions: The Enabling Role of Individuals' Social Position. Organization 13 (5): 653-676.

Bennett, C. 1991. What Is Policy Convergence and What Causes It? British Journal of Political Science 21 (2): 215-233. https://doi.org/10.1017/ S0007123400006116.

Blau, P.M., and W.R. Scott. 2003. Formal Organizations: A Comparative Approach. Stanford: Stanford University Press.

Bleiklie, I., J. Enders, and B. Lepori. 2015. Organizations as Penetrated Hierarchies: Environmental Pressures and Control in Professional Organizations. Organisation Studies 36 (7): 873-896.

- 2017. Organizational Configurations of Modern Universities, Institutional Logics and Public Policies - Towards an Integrative Framework. In Managing Universities: Policy and Organizational Change from a Western European Comparative Perspective, Palgrave Studies in Global Higher Education, ed. I. Bleiklie, J. Enders, and B. Lepori, 303-326. Cham: Springer International Publishing. 
Brunsson, Nils, and Kerstin Sahlin-Andersson. 2000. Constructing Organizations: The Example of Public Sector Reform. Organization Studies 21 (4): 721-746. https://doi.org/10.1177/0170840600214003.

Bryman, Alan. 2006. Integrating Quantitative and Qualitative Research: How Is It Done? Qualitative Research 6 (1): 97-113. https://doi.org/10.1177/ 1468794106058877.

Campbell, J.L., and O.K. Pedersen. 2014. The National Origins of Policy Ideas. Knowledge Regimes in the United States, France, Germany and Denmark. Princeton: Princeton University Press.

Castells, M., and P. Himanen. 2004. The Information Society and the Welfare State: The Finnish Model. Oxford: Oxford University Press.

Christensen, T., and P. Lxgreid. 2007. Transcending New Public Management: The Transformation of Public Sector Reforms. Aldershot: Ashgate.

- 2017. Introduction. Accountability and Welfare State Reforms. In The Routledge Handbook to Accountability and Welfare State Reforms in Europe, ed. T. Christensen and P. Lxgreid, 1-11. Oxon: Routledge.

Clark, B.R. 1983. The Higher Education System: Academic Organization in CrossNational Perspective. Los Angeles, CA: University of California Press.

- 1998. Creating Entrepreneurial Universities: Organizational Pathways of Transformation. New York: Pergamon.

Cohen, M.D., and J.G. March. 1974. Leadership and Ambiguity: The American College President. Berkeley, CA: Carnegie Commission on Higher Education.

Czarniawska-Joerges, B., and G. Sevón. 2005. Global Ideas: How Ideas, Objects and Practices Travel in a Global Economy. Malmö: Liber \& Copenhagen Business School Press.

de Boer, H., and J. Enders. 2017. Working in the Shadow of Hierarchy: Organisational Autonomy and Venues of External Influence in European Universities. In Managing Universities. Policy and Organizational Change from a Western European Comparative Perspective, ed. I. Bleiklie, J. Enders, and B. Lepori, 57-84. Cham: Palgrave Macmillan.

de Jong, S.P.L., J. Smit, and L. van Drooge. 2016. Scientists' Response to Societal Impact Policies. A Policy Paradox. Science and Public Policy 43 (1): 102-114.

Deephouse, D., and M. Suchman. 2008. Legitimacy in Organizational Institutionalism. In The SAGE Handbook of Organizational Institutionalism, ed. R. Greenwood, K. Sahlin Christine Oliver, and R. Suddaby, 49-77. London and Thousand Oaks: Sage.

Denzin, Norman K., and Yvonne S. Lincoln, eds. 2011. Handbook of Qualitative Research. 4th ed. Thousand Oaks: Sage Publisher.

DiMaggio, P., and W. Powell. 1983. The Iron Cage Revisited: Institutional Isomorphism and Collective Rationality in Organizational Fields. American Sociological Review 48 (2): 147-160.

Etzkowitz, Henry. 2001. The Second Academic Revolution and the Rise of Entrepreneurial Science. Technology and Society Magazine 20 (2): 18-29. 
Etzkowitz, H., M. Ranga, M. Benner, L. Guaranys, A.M. Maculan, and R. Kneller. 2008. Pathways to the Entrepreneurial University: Towards a Global Convergence. Science and Public Policy 35 (9): 681-695. https://doi.org/10. 3152/030234208x389701.

Etzkowitz, H., A. Webster, C. Gebhardt, and B.R.C. Terra. 2000. The Future of the University and the University of the Future: Evolution of Ivory Tower to Entrepreneurial Paradigm. Research Policy 29 (2): 313-330.

European Commission. 2006. Delivering on the Modernisation Agenda for Universities: Education, Research and Innovation. COM (2006) 208 final. Brussels: European Commission.

- 2011. Supporting Growth and Jobs - An Agenda for the Modernisation of Europe's Higher Education Systems. COM (2011) 567 final. Brussels: European Commission.

Fumasoli, T., A. Gornitzka, and P. Maassen. 2014. University Autonomy and Organizational Change Dynamics. ARENA Working Paper 8, July 2014.

Fumasoli, T., and B. Stensaker. 2013. Organizational Studies in Higher Education: A Reflection on Historical Themes and Prospective Trends. Higher Education Policy 26 (4): 479.

Goldstein, Kenneth. 2002. Getting in the Door: Sampling and Completing Elite Interviews. Political Science \& Politics 35 (4): 669-672.

Gornitzka, Å. 1999. Governmental Policies and Organizational Change in Higher Education. Higher Education 38 (1999): 5-31.

Gornitzka, Å., B. Stensaker, J.-C. Smeby, and H. De Boer. 2004. Contract Arrangements in the Nordic Countries: Solving the Efficiency-Effectiveness Dilemma? Higher Education in Europe 29 (1): 87-101. https://doi.org/10.1 080/03797720410001673319.

Greenwood, R., Christine Oliver, K. Sahlin, and R. Suddaby. 2008. The SAGE Handbook of Organizational Institutionalism. London: SAGE.

Hay, Colin, and Daniel Wincott. 1998. Structure, Agency and Historical Institutionalism. Political Studies 46 (5): 951-957. https://doi.org/ $10.1111 / 1467-9248.00177$.

Hessels, L.K., H. van Lente, and R. Smits. 2009. In Search of Relevance: The Changing Contract Between Science and Society. Science and Public Policy 36 (5): 387-401.

Hilson, M. 2008. The Nordic Model: Scandinavia Since 1945. London: Reaktion Books.

Hölttä, S., and K. Karjalainen. 1997. Cybernetic Institutional Management Theory and Practice. Tertiary Education and Management 3 (3): 229-236.

Holzinger, K., and C. Knill. 2005. Causes and Conditions of Cross-National Policy Convergence. Journal of European Public Policy 12 (5): 775-796.

Hood, C. 1991. A Public Management for All Seasons? Public Administration 69 (1): 3-19. https://doi.org/10.1111/j.1467-9299.1991.tb00779.x. 
1995. The 'New Public Management' in the 1980s: Variations on a Theme. Accounting, Organizations and Society 20 (2-3): 93-109. https://doi. org/10.1016/0361-3682(93)e0001-w.

Hood, C., O. James, B.G. Peters, and C. Scott, eds. 2004. Controlling Modern Government: Variety, Commonality and Change. Cheltenham: Edward Elgar.

Kallo, J. 2009. OECD Education Policy: A Comparative and Historical Study Focusing on the Thematic Reviews of Tertiary Education. Helsinki: Finnish Educational Research Association.

Kivistö, Jussi, Elias Pekkola, and Anu Lyytinen. 2017. The Influence on Performance-Based Management on Teaching and Research Performance of Finnish Senior Academics. Tertiary Education and Management 23 (3): 260-275.

Knill, Christoph. 2005. Introduction: Cross-National Policy Convergence: Concepts, Approaches and Explanatory Factors. Journal of European Public Policy 12 (5): 764-774. https://doi.org/10.1080/13501760500161332.

Krücken, G. 2011. A European Perspective on New Modes of University Governance and Actorhood. Research \& Occasional Paper Series: CSHE.17.11.

Krücken, G., and F. Meier. 2006. Turning the University into an Organizational Actor. In Globalization and Organization: World Society and Organizational Change, ed. G.S. Drori, J.W. Meyer, and H. Hwang, 241-257. Oxford: Oxford University Press.

Maassen, P. 2009. The Modernisation of European Higher Education: National Policy Dynamics. In From Governance to Identity, ed. Alberto Amaral, Ivar Bleiklie, and Christine Musselin, 95-112. Dordrecht: Springer.

Maassen, P., and J.P. Olsen. 2007. University Dynamics and European Integration. Dordrecht: Springer.

Maassen, Peter, and Bjørn Stensaker. 2011. The Knowledge Triangle, European Higher Education Policy Logics and Policy Implications. Higher Education 61 (6): 757-769. https://doi.org/10.1007/s10734-010-9360-4.

March, J.G., and J.P. Olsen. 1979. Ambiguity and Choice in Organizations. Bergen: Universitetsforlaget.

- 2006a. Elaborating the 'New Institutionalism. In The Oxford Handbook of Political Institutions, ed. R.A. Rhodes, S.A. Binder, and B.A. Rockman, 3-22. Oxford: Oxford University Press.

- 2006b. The Logic of Appropriateness. In The Oxford Handbook of Public Policy, ed. M. Moran, M. Rein, and R. Goodin, 689-708. Oxford: Oxford University Press.

Moisio, J. 2014. Understanding the Significance of EU Higher Education Policy Cooperation in Finnish Higher Education Policy. Doctoral Diss., School of Management, University of Tampere, Tampere University Press.

Musselin, C. 2007. Are Universities Specific Organisations? In Towards a Multiversity? Universities Between Global Trends and National Traditions, ed. 
G. Krücken, A. Kosmützky, and M. Torka, 63-84. Bielefeld: Transaction Publishers.

Neave, G. 2003. The Bologna Declaration: Some of the Historic Dilemmas Posed by the Reconstruction of the Community in Europe's Systems of Higher Education. Educational Policy 17 (1): 141-164.

Norden. 2014. The Nordic Model-Challenged but Capable of Reform. Copenhagen: Nordic Council of Ministers.

Oliver, Christine. 1991. Strategic Responses to Institutional Processes. Academy of Management Review 16 (1): 145-179.

Olsen, J.P. 1988. Administrative Reform and Theories of Organization. In Organizing Governance, Governing Organizations, ed. C. Campbell and B.G. Peters, 233-254. Pittsburgh: University of Pittsburgh Press.

Olsen, J.P. 2007. The Institutional Dynamics of the European University. In University Dynamics and European Integration, ed. P. Maassen and J.P. Olsen, 25-54. Dordrecht: Springer.

Pfeffer, J. 1997. New Directions for Organization Theory: Problems and Prospects. Oxford: Oxford University Press.

Pinheiro, R. 2012. In the Region, for the Region? A Comparative Study of the Institutionalisation of the Regional Mission of Universities. PhD Diss., Faculty of Education, University of Oslo.

Pinheiro, R., P. Benneworth, and G.A. Jones, eds. 2012. Universities and Regional Development: A Critical Assessment of Tensions and Contradictions. Milton Park and New York: Routledge.

Pinheiro, R., L. Geschwind, and T. Aarrevaara. 2014. Nested Tensions and Interwoven Dilemmas in Higher Education: The View from the Nordic Countries. Cambridge Journal of Regions, Economy and Society 7 (2): 233-250. https://doi.org/10.1093/cjres/rsu002.

Pinheiro, R., and B. Stensaker. 2013. Designing the Entrepreneurial University: The Interpretation of a Global Idea. Public Organization Review 14 (4): 1-20. https://doi.org/10.1007/s11115-013-0241-z.

Powell, W., and J. Colyvas. 2008. Microfoundations of Institutional Theory. In The SAGE Handbook of Organizational Institutionalism, ed. R. Greenwood, K. Sahlin Christine Oliver, and R. Suddaby, 276-298. London: Sage.

Powell, W.W., and P. DiMaggio. 1991. The New Institutionalism in Organizational Analysis. Chicago: University of Chicago Press.

Ragin, Charles C., and Benoît Rihoux. 2009. Configurational Comparative Methods. Los Angeles: Sage.

Ramirez, F.O. 2010. Accounting for Excellence: Transforming Universities into Organizational Actors. In Higher Education, Policy, and the Global Competition Phenomenon, ed. Laura Portnoi, Val Rust, and Sylvia Bagely, 43-58. Basingstoke: Palgrave.

Ramirez, Francisco O., and T. Christensen. 2013. The Formalization of the University: Rules, Roots, and Routes. Higher Education 65 (6): 695-708. 
Rip, Arie. 2004. Strategic Research, Post-modern Universities and Research Training. Higher Education Policy 17 (2): 153-166.

Sabatier, P. 2005. From Policy Implementation to Policy Change: A Personal Odyssey. In Reform and Change in Higher Education. Higher Education Dynamics, ed. Å. Gornitzka, M. Kogan, and A. Amaral, vol. 8. Dordrecht: Springer.

Scott, W.R. 2003. Organizations: Rational, Natural, and Open Systems. New York: Prentice Hall.

- 2008. Institutions and Organizations: Ideas and Interests. London: Sage.

Seeber, Marco, Benedetto Lepori, Martina Montauti, Jürgen Enders, Harry De Boer, Elke Weyer, Ivar Bleiklie, Kristin Hope, Svein Michelsen, and Gigliola Nyhagen Mathisen. 2015. European Universities as Complete Organizations? Understanding Identity, Hierarchy and Rationality in Public Organizations. Public Management Review 17 (10): 1444-1474.

Selznick, Philip. 1966. TVA and the Grass Roots: A Study in the Sociology of Formal Organization. New York: Harper \& Row.

Selznick, Philip. 1984. Leadership in Administration: A Sociological Interpretation. Berkeley, CA: University of California Press.

Shahjahan, R.A., and M. Madden. 2015. Uncovering the Images and Meanings of International Organizations (IOs) in Higher Education Research. Higher Education 69 (5): 705-717. https://doi.org/10.1007/s10734-014-9801-6.

Slaughter, Sheila, and Brendan Cantwell. 2012. Transatlantic Moves to the Market: The United States and the European Union. Higher Education 63 (5): 583-606. https://doi.org/10.1007/s10734-011-9460-9.

Slaughter, S., and L.L. Leslie. 1999. Academic Capitalism: Politics, Policies, and the Entrepreneurial University. Baltimore: Johns Hopkins University Press.

Slaughter, S., and B.J. Taylor, eds. 2016. Competitive Advantage: Stratification, Privatization and Vocationalization of Higher Education in the US, EU, and Canada, Higher Education Dynamics. Dordrecht: Springer.

Ståhle, P., and L. Åberg. 2012. Voiko yliopiston uudistumista johtaa? (Can the Renewal of Universities Be Managed?). In Innostava yliopisto (An Inspiring University), ed. Pirjo Ståhle and Antti Ainamo. Gaudeamus.

Stensaker, B. 2014. Troublesome Institutional Autonomy: Governance and the Distribution of Authority in Norwegian Universities. In International Trends in University Governance: Autonomy, Self-Government and the Distribution of Authority, ed. M. Shattock, 34-48. New York: Routledge.

Tapper, T., and D. Palfreyman. 2011. Oxford, the Collegiate University: Conflict, Consensus and Continuity. Dordrecht: Springer.

Teichler, U. 2005. Research on Higher Education in Europe. European Journal of Education 40 (4): 447.

Thompson, J.D. 2008. Organizations in Action: Social Science Bases of Administrative Theory. 5th ed. New Brunswick: Transaction Publishers. 
Trow, M., and M. Burrage. 2010. Twentieth-Century Higher Education: Elite to Mass to Universal. Baltimore: Johns Hopkins University Press.

Verhoest, K., B.G. Peters, G. Bouckaert, and B. Verschuere. 2004. The Study of Organisational Autonomy: A Conceptual Review. Public Administration and Development 24: 101-118. https://doi.org/10.1002/pad.316.

Voegtle, E.M., C. Knill, and M. Dobbins. 2011. To What Extent Does Transnational Communication Drive Cross-National Policy Convergence? The Impact of the Bologna-Process on Domestic Higher Education Policies. Higher Education 61: 77. https://doi.org/10.1007/s10734-010-9326-6.

Weick, K.E. 1976. Educational Organizations as Loosely Coupled Systems. Administrative Science Quarterly 21 (1): 1-19.

Whitley, R. 2008. Constructing Universities as Strategic Actors: Limitations and Variations. In The University in the Market, ed. L. Engwall and D. Weaire. London: Portland Press Ltd.

Williams, G., and I. Kitaev. 2005. Overview of National Policy Contexts for Entrepreneurialism in Higher Education Institutions. Higher Education Management and Policy 17 (3): 125-141.

Witte, Johanna. 2008. Aspired Convergence, Cherished Diversity: Dealing with the Contradictions of Bologna. Tertiary Education and Management 14 (2): 81-93. https://doi.org/10.1080/13583880802051840.

Zechlin, L. 2010. Strategic Planning in Higher Education. In International Encyclopedia of Education, ed. P. Peterson, E. Baker, and B. McGaw, 256-263. Amsterdam: Elsevier.

Open Access This chapter is licensed under the terms of the Creative Commons Attribution 4.0 International License (http://creativecommons.org/licenses/ by $/ 4.0 /$ ), which permits use, sharing, adaptation, distribution and reproduction in any medium or format, as long as you give appropriate credit to the original author(s) and the source, provide a link to the Creative Commons licence and indicate if changes were made.

The images or other third party material in this chapter are included in the chapter's Creative Commons licence, unless indicated otherwise in a credit line to the material. If material is not included in the chapter's Creative Commons licence and your intended use is not permitted by statutory regulation or exceeds the permitted use, you will need to obtain permission directly from the copyright holder.

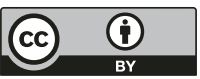

